\title{
RELIABILITY AND MAINTENANCE ANALYSIS OF CCTV SYSTEMS USED IN RAIL TRANSPORT
}

\section{ANALIZA NIEZAWODNOŚCIOWO-EKSPLOATACYJNA SYSTEMÓW MONITORINGU WIZYJNEGO STOSOWANYCH W OBIEKTACH KOLEJOWYCH}

\author{
Mirosław Siergiejczyk ${ }^{1}$, Jacek Paś ${ }^{2}$, Adam Rosiński ${ }^{3}$ \\ ${ }^{1}$ Institute of Railway, ${ }^{2}$ Military University of Technology, \\ ${ }^{3}$ Warsaw University of Technology \\ e-mail:msi@wt.pw.edu.pl;jpas@wat.edu.pl,adro@wt.pw.edu.pl
}

\begin{abstract}
CCTV systems are widely used across plethora of industrial areas including transport, where their function is to support transport telematics systems. Among others, they are used to ensure travel safety. This paper presented a reliability and maintenance analysis of CCTV. It led to building a relationships graph and then Chapman-Kolmogorov system of equations was derived to describe it. Drawing on those equations, relationships for calculating probability of system staying in state of full ability $S_{P Z}$, state of the impendency over safety $S_{Z B}$ as well as state of unreliability of safety $S_{B}$ were derived.
\end{abstract}

Keywords: Closed Circuit Television, reliability, operation and maintenance

Streszczenie: Systemy monitoringu wizyjnego sq wykorzystywane $w$ wielu obszarach przemystu, w tym także $w$ transporcie. Wspomagaja wówczas realizacje funkcji, które sq świadczone przez systemy telematyki transportu. W artykule zaprezentowano analize niezawodnościowo-eksploatacyjna systemów monitoringu wizyjnego. Umożliwito to zaproponowanie grafu relacji, zaś następnie na utworzenie układu równań Kotmogorowa-Chapmana opisujących go. Na tej podstawie możliwe byto wyznaczenie zależności pozwalajacych na obliczenie wartości prawdopodobieństw przebywania systemu w stanach: petnej zdatności $S_{P Z}$ zagrożenia bezpieczeństwa $S_{Z B I}$ oraz zawodności bezpieczeństwa $S_{B}$.

Słowa kluczowe: systemy monitoringu wizyjnego, niezawodność, eksploatacja 
Reliability and maintenance analysis of CCTV systems used in rail transport Analiza niezawodnościowo-eksploatacyjna systemów monitoringu wizyjnego...

\section{Introduction}

CCTV systems are widely used across plethora of industrial areas including transport [16], where their function is to support transport telematics systems $[9,21,22]$. Among others, they are used to ensure travel safety. Then, the CCTV systems can be classified as electronic safety systems. They are used in both stationary facilities (e.g. railway stations, level crossings) and mobile objects (e.g. electric multiple units, passenger carriages, electric locomotives). Thanks to this, the level of safety of both travellers and transported cargo increases.

The CCTV systems installed in rail transport work in various maintenance conditions $[4,8]$. Because they are elements responsible for safety, they should keep their usability. Therefore, the reliability and maintenance analysis of these systems is important. So far, the authors have analysed these systems' structures in terms of reliability. Some developments also concerned the reliability and maintenance analysis $[17,19]$ taking into account the relationships in the system with particular reference to issues related to power supply [15]. The paper showed general deliberations concerning the reliability and maintenance analysis of the CCTV systems with particular reference to restoration to the state of usability.

\section{Characteristics of the CCTV systems}

The Closed Circuit Television (CCTV) is used as one of the subsystems of transport telematics systems. It is a set of technical and programme measures designed for observing, detecting, recording, and signalling conditions indicating the existence of danger. They may include (depending on configuration) the following basic devices $[6,13,14]$ :

- cameras with lenses,

- transmission media with interfaces,

- recorders,

- monitors,

- power systems,

- lighting systems,

- other systems (e.g. protection systems, processing devices, filter systems, and elements screening electromagnetic disturbances).

Fig. 1 illustrates the most common CCTV system, which consists of cameras (usually up to 16), a digital video recorder, and two monitors. The first monitor shows the overview of all connected cameras. The overview can be divided (usually into 4, 9, and 16 fields). On the second monitor, a picture from the camera that currently detected motion through a motion detection system is shown. Events are recorded digitally via a digital video recorder on HDD hard drives. The digital video recorder may have a lot of functions, such as: a sequential switcher, a video splitter, an event recording system integrated with motion detection. It is most often equipped with an Ethernet card as well, thanks to which remote handling via the Internet (the Intranet) using the TCP/IP protocol is possible [7]. Such solutions are used in, among others, railway stations. 


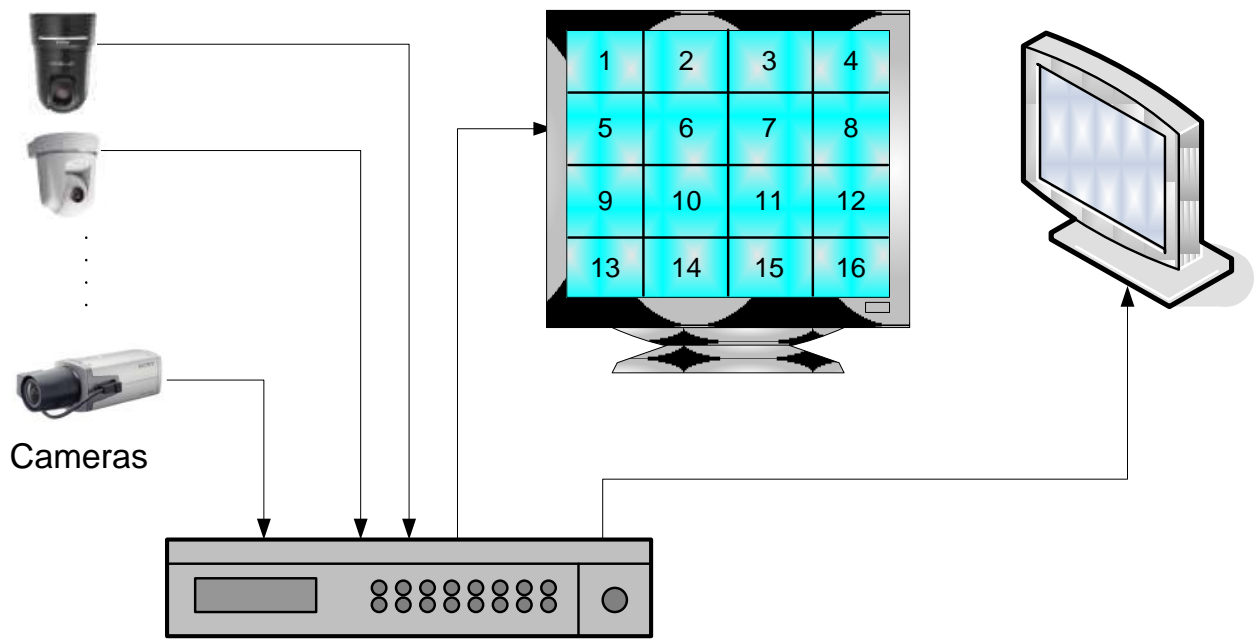

Digital Video Recorder

Fig. 1 An example of the CCTV system

In rail transport, there are different kinds of electromagnetic disturbances. Therefore, it is important to use solutions that are resistant to these disturbances, or minimise their effect $[3,12]$. One of the used solutions is the use of a transmission medium - an optical fibre [18]. The advantages of this solution are, among others, low attenuation, resistance to external magnetic and electric fields, and the lack of outwards emission of energy. It is used between facilities situated within a vast rail area. It requires the use of converters that convert electrical signals into optical ones and vice versa. Vibrations are an important issue that should be taken into account during the design of the CCTV systems (especially in mobile transport objects) [2].

\section{Selected issues of reliability and maintenance analysis of CCTV systems used in rail transport}

Analysing the CCTV system used in rail transport, it can be said that it has a mixed structure $[1,5,20]$. For the purpose of further analysis, a management and archiving centre, as well as cameras were distinguished. Damage of the management and archiving centre causes the transition of the system from the state of complete usability $\mathrm{R}_{\mathrm{O}}(\mathrm{t})$ to the state of unreliability of safety $\mathrm{Q}_{\mathrm{B}}(\mathrm{t})$. Damage of one of the cameras causes the transition of the system from the state of complete usability $\mathrm{R}_{\mathrm{O}}(\mathrm{t})$ to the state of the impendency over safety $\mathrm{Q}_{\mathrm{ZB} 1}(\mathrm{t})$. Transitions restoring the state of complete usability are also possible (renewal process $[10,11]$ ):

- from the state of the impendency over safety $(\mathrm{Q})_{\mathrm{ZB} 1}(\mathrm{t})$ to the state of complete usability $\mathrm{R}_{\mathrm{O}}(\mathrm{t})$ with the intensity of $\mu_{\mathrm{ZB} 2}$,

- from the state of the unreliability of safety $(\mathrm{Q})_{\mathrm{B}}(\mathrm{t})$ to the state of complete usability $R_{O}(t)$ with the intensity of $\mu_{\mathrm{ZB} 1}$. 
Reliability and maintenance analysis of CCTV systems used in rail transport Analiza niezawodnościowo-eksploatacyjna systemów monitoringu wizyjnego...

Fig. 2 illustrates the relationships in the considered system in terms of the reliability and maintenance aspect.

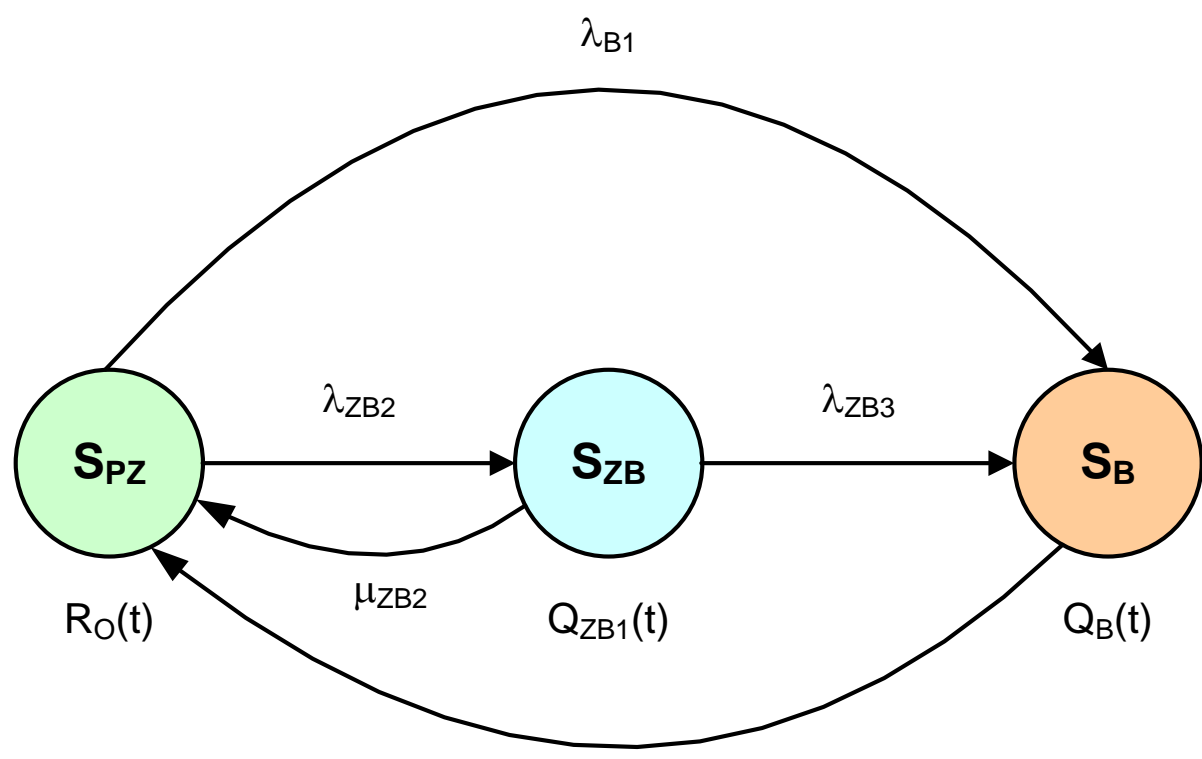

$\mu_{\mathrm{B} 1}$

Fig. 2 Reliability and maintenance relationships in the CCTV system

Markings in fig.:

$R_{O}(t) \quad-$ the probability function of the system staying in the state of complete usability $S_{P Z}$

$Q_{Z B}(t) \quad-$ the probability function of the system staying in the state of the impendency over safety $S_{Z B}$,

$Q_{B}(t) \quad-$ the probability function of the system staying in the state of unreliability of safety $S_{B}$,

$\lambda_{B 1}-$ intensity of transitions of the management and archiving centre,

$\lambda_{Z B 2}, \lambda_{Z B 3}-$ intensity of transitions of cameras,

$\mu_{B 1} \quad-$ intensity of restoration of the state of usability of the management and archiving centre,

$\mu_{Z B 2}-$ intensity of restoration of the state of usability of the cameras.

The system shown in Fig. 2 can be described by the following ChapmanKolmogorov equations:

$$
\begin{aligned}
& R_{0}^{\prime}(t)=-\lambda_{B 1} \cdot R_{0}(t)-\lambda_{Z B 2} \cdot R_{0}(t)+\mu_{Z B 2} \cdot Q_{Z B 1}(t)+\mu_{B 1} \cdot Q_{B}(t) \\
& Q_{Z B 1}^{\prime}(t)=\lambda_{Z B 2} \cdot R_{0}(t)-\lambda_{Z B 3} \cdot Q_{Z B 1}(t)-\mu_{Z B 2} \cdot Q_{Z B 1}(t) \\
& Q_{B}^{\prime}(t)=\lambda_{B 1} \cdot R_{0}(t)+\lambda_{Z B 3} \cdot Q_{Z B 1}(t)-\mu_{B 1} \cdot Q_{B}(t)
\end{aligned}
$$


Assuming the baseline condition:

$$
\begin{aligned}
& R_{0}(O)=1 \\
& Q_{Z B 1}(O)=Q_{B}(O)=0
\end{aligned}
$$

and applying the Laplace transform, we obtain the following system of linear equations:

$$
\begin{aligned}
& s \cdot R_{0}^{*}(s)-1=-\lambda_{B 1} \cdot R_{0}^{*}(s)-\lambda_{Z B 2} \cdot R_{0}^{*}(s)+\mu_{Z B 2} \cdot Q_{Z B 1}^{*}(s)+\mu_{B 1} \cdot Q_{B}^{*}(s) \\
& s \cdot Q_{Z B 1}^{*}(s)=\lambda_{Z B 2} \cdot R_{0}^{*}(s)-\lambda_{Z B 3} \cdot Q_{Z B 1}^{*}(s)-\mu_{Z B 2} \cdot Q_{Z B 1}^{*}(s) \\
& s \cdot Q_{B}^{*}(s)=\lambda_{B 1} \cdot R_{0}^{*}(s)+\lambda_{Z B 3} \cdot Q_{Z B 1}^{*}(s)-\mu_{B 1} \cdot Q_{B}^{*}(s)
\end{aligned}
$$

Probabilities of the system staying in the distinguished maintenance states from the symbolic (Laplace's) perspective are in the following form:

$$
\begin{aligned}
& R_{0}^{*}(s)= \frac{s^{2}+s \cdot \mu_{B 1}+s \cdot \lambda_{Z B 3}+s \cdot \mu_{Z B 2}+\mu_{B 1} \cdot \lambda_{Z B 3}+\mu_{B 1} \cdot \mu_{Z B 2}}{s^{3}+s^{2} \cdot\left(\lambda_{B 1}+\mu_{B 1}+\lambda_{Z B 2}+\lambda_{Z B 3}+\mu_{Z B 2}\right)+} \\
&+ s \cdot\left(\begin{array}{l}
\lambda_{B 1} \cdot \lambda_{Z B 3}+\lambda_{B 1} \cdot \mu_{Z B 2}+\mu_{B 1} \cdot \lambda_{Z B 2}+\mu_{B 1} \cdot \lambda_{Z B 3}+ \\
+\mu_{B 1} \cdot \mu_{Z B 2}+\lambda_{Z B 2} \cdot \lambda_{Z B 3}
\end{array}\right) \\
& Q_{Z B 1}^{*}(s)= \frac{s \cdot \lambda_{Z B 2}+\mu_{B 1} \cdot \lambda_{Z B 2}}{s^{3}+s^{2} \cdot\left(\lambda_{B 1}+\mu_{B 1}+\lambda_{Z B 2}+\lambda_{Z B 3}+\mu_{Z B 2}\right)+} \\
&+s \cdot\left(\begin{array}{l}
\lambda_{B 1} \cdot \lambda_{Z B 3}+\lambda_{B 1} \cdot \mu_{Z B 2}+\mu_{B 1} \cdot \lambda_{Z B 2}+\mu_{B 1} \cdot \lambda_{Z B 3}+ \\
+\mu_{B 1} \cdot \mu_{Z B 2}+\lambda_{Z B 2} \cdot \lambda_{Z B 3}
\end{array}\right) \\
& Q_{B}^{*}(s)=\left.\begin{array}{l}
s \cdot \lambda_{B 1}+\lambda_{B 1} \cdot \lambda_{Z B 3}+\lambda_{B 1} \cdot \mu_{Z B 2}+\lambda_{Z B 2} \cdot \lambda_{Z B 3} \\
s^{3}+s^{2} \cdot\left(\lambda_{B 1}+\mu_{B 1}+\lambda_{Z B 2}+\lambda_{Z B 3}+\mu_{Z B 2}\right)+
\end{array}\right) \\
&+s \cdot\left(\begin{array}{l}
\lambda_{B 1} \cdot \lambda_{Z B 3}+\lambda_{B 1} \cdot \mu_{Z B 2}+\mu_{B 1} \cdot \lambda_{Z B 2}+\mu_{B 1} \cdot \lambda_{Z B 3}+ \\
+\mu_{B 1} \cdot \mu_{Z B 2}+\lambda_{Z B 2} \cdot \lambda_{Z B 3}
\end{array}\right)
\end{aligned}
$$

The solution of the above mentioned set of equations in the field of time is the next step of the analysis and is not discussed there.

Received relationships (4) enable the determination of the probabilities of the CCTV system staying in the state of complete usability $R_{O}$, the impendency over safety $\mathrm{Q}_{\mathrm{ZB} 1}$, and unreliability of safety $\mathrm{Q}_{\mathrm{B}}$. 
Reliability and maintenance analysis of CCTV systems used in rail transport Analiza niezawodnościowo-eksploatacyjna systemów monitoringu wizyjnego...

\section{Reliability and maintenance modelling of CCTV systems used in rail transport}

Simulation and computer methods and studies give an opportunity to determine influence of the reliability and maintenance parameters of particular elements on reliability of the entire system relatively fast. Of course, the reliability structure of the system and the reliability characteristics of the particular elements and systems must be known in advance.

Thanks to the computer assistance, calculations enabling determination of the probability of the system staying in the state of complete usability can be made. Such procedure is shown in the following example.

\section{Example}

Assuming the following values describing the analysed system:

- duration of research - 1 year (the value of this time is given in the units as hours [h]):

$$
\mathrm{t}=8760[h]
$$

- reliability $\mathrm{R}_{\mathrm{B} 1}$ :

$$
\mathrm{R}_{\mathrm{B} 1}(t)=0,99
$$

- reliability $R_{Z B 2}$ :

$$
\mathrm{R}_{\mathrm{ZB} 2}(t)=0,95
$$

- reliability $\mathrm{R}_{\mathrm{ZB} 3}$ :

$$
\mathrm{R}_{\mathrm{ZB} 3}(t)=0,97
$$

Knowing the value of reliability $\mathrm{R}_{\mathrm{B} 1}$, you can estimate the intensity of transitions from the state of complete usability to the state of unreliability of safety. Assuming the simplest, exponential model of distribution of usability time, we can use the following relationship:

$$
\mathrm{R}_{\mathrm{B} 1}(\mathrm{t})=\mathrm{e}^{-\lambda_{\mathrm{B} 1} \mathrm{t}} \text { for } t \geq 0
$$

so

$$
\lambda_{\mathrm{B} 1}=-\frac{\ln \mathrm{R}_{\mathrm{B} 1}(\mathrm{t})}{\mathrm{t}}
$$

For $\mathrm{t}=8760[h]$ and $\mathrm{R}_{\mathrm{B} 1}(t)=0,99$ we obtain:

$$
\lambda_{\mathrm{B} 1}=-\frac{\ln \mathrm{R}_{\mathrm{B} 1}(\mathrm{t})}{\mathrm{t}}=-\frac{\ln 0,99}{8760}=1,147298 \cdot 10^{-6}\left[\frac{1}{\mathrm{~h}}\right]
$$

Knowing the value of reliability $\mathrm{R}_{\mathrm{ZB} 2}$, the intensity of transitions from the state of complete usability to the state of impendency over safety can be estimated. 
Assuming the simplest, exponential model of distribution of usability time, the following relationship can be used:

$$
\mathrm{R}_{\mathrm{ZB} 2}(\mathrm{t})=\mathrm{e}^{-\lambda_{\mathrm{ZB} 2} \mathrm{t}} \text { for } t \geq 0
$$

so

$$
\lambda_{\mathrm{ZB} 2}=-\frac{\ln \mathrm{R}_{\mathrm{ZB} 2}(\mathrm{t})}{\mathrm{t}}
$$

For $\mathrm{t}=8760[h]$ and $\mathrm{R}_{\mathrm{ZB} 2}(t)=0,95$ we obtain:

$$
\lambda_{\mathrm{ZB} 2}=-\frac{\ln \mathrm{R}_{\mathrm{ZB} 2}(\mathrm{t})}{\mathrm{t}}=-\frac{\ln 0,95}{8760}=5,855398 \cdot 10^{-6}\left[\frac{1}{\mathrm{~h}}\right]
$$

Knowing the value of reliability $\mathrm{R}_{\mathrm{ZB} 3}$, the intensity of transitions from the state of complete usability to the state of impendency over safety can be estimated. Assuming the simplest, exponential model of distribution of usability time, the following relationship can be used:

$$
\mathrm{R}_{\mathrm{ZB} 3}(\mathrm{t})=\mathrm{e}^{-\lambda_{\mathrm{ZB} 3} \mathrm{t}} \text { for } t \geq 0
$$

so

$$
\lambda_{\mathrm{ZB} 3}=-\frac{\ln \mathrm{R}_{\mathrm{ZB} 3}(\mathrm{t})}{\mathrm{t}}
$$

For $\mathrm{t}=8760[h]$ and $\mathrm{R}_{\mathrm{ZB} 3}(t)=0,97$ we obtain:

$$
\lambda_{\mathrm{ZB} 3}=-\frac{\ln \mathrm{R}_{\mathrm{ZB} 3}(\mathrm{t})}{\mathrm{t}}=-\frac{\ln 0,97}{8760}=3,477078 \cdot 10^{-6}\left[\frac{1}{\mathrm{~h}}\right]
$$

We obtain:

$$
\begin{aligned}
5,43 \cdot 10^{42} \cdot s+5,43 \cdot 10^{42} \cdot \mu_{B 1}+1,56 \cdot 10^{48} \cdot s^{2}+1,56 \cdot 10^{48} \cdot s \cdot \mu_{B 1}+ \\
R_{0}^{*}(s)=\frac{+1,56 \cdot 10^{48} \cdot s \cdot \mu_{Z B 2}+1,56 \cdot 10^{48} \cdot \mu_{B 1} \cdot \mu_{Z B 2}}{3,8 \cdot 10^{37} \cdot s+1,56 \cdot 10^{48} \cdot s^{2} \cdot \mu_{B 1}+1,56 \cdot 10^{48} \cdot s^{2} \cdot \mu_{Z B 2}+1,63 \cdot 10^{43} \cdot s^{2}+} \\
+1,56 \cdot 10^{48} \cdot s^{3}+1,45 \cdot 10^{43} \cdot s \cdot \mu_{B 1}+1,79 \cdot 10^{42} \cdot s \cdot \mu_{Z B 2}+1,56 \cdot 10^{48} \cdot s \cdot \mu_{B 1} \cdot \mu_{Z B 2}
\end{aligned}
$$

Adopting $\mu_{Z B 2}=0,2, \mu_{B 1}=0,1$ and applying the Laplace transform, we obtain:

$$
R_{O}=0,99995925
$$

The practical application of the presented deliberations allows to determinate the influence of the values of transitions intensity $\mu_{Z B 2}$ and $\mu_{B 1}$ on the probability of the system staying in the state of complete usability $\mathrm{R}_{\mathrm{O}}$. Intensities $\mu_{Z B 2}$ and $\mu_{B 1}$ must be understood as reciprocals of times $t_{Z B 2}$ and the $t_{B 1}$ intensities, which determine the time of restoration of the state of complete usability. 
Reliability and maintenance analysis of CCTV systems used in rail transport Analiza niezawodnościowo-eksploatacyjna systemów monitoringu wizyjnego...

Generalising the presented deliberations, it can be concluded that, analysing the operation of the CCTV systems, their reliability and maintenance properties, as well as the influence of duration of renewal that will restore the state of complete usability should be taken into account.

\section{Conclusion}

The issue presented in the paper concerned the CCTV systems used in rail transport as the transport telematics system. This paper presented the reliability and maintenance analysis of these systems. It led to building a relationships graph and then Chapman-Kolmogorov system of equations was derived to describe it. Drawing on those equations, relationships for calculating probability of system staying in state of complete usability $\mathrm{S}_{\mathrm{PZ}}$, state of the impendency over safety $\mathrm{S}_{\mathrm{ZB} 1}$ as well as state of unreliability of safety $S_{B}$ were derived. A particular emphasis was put on the issues of restoring the state of complete usability. In further research, it is planned to conduct analyses allowing to determine the influence of times of restoration of the state of complete usability on the probability of the system staying in the distinguished states.

\section{Literature}

[1] Będkowski L., Dąbrowski T.: The basis of exploitation, part II: The basis of exploational reliability. Military Academy of Technology, Warsaw 2006.

[2] Burdzik R., Konieczny L.: Research on structure, propagation and exposure to general vibration in passenger car for different damping parameters, Journal of Vibroengineering Vol. 15, Issue 4, 2013, p. 1680-1688.

[3] Duer S., Zajkowski K., Duer R., Paś J.: Designing of an effective structure of system for the maintenance of a technical object with the using information from an artificial neural network. Neural Computing \& Applications 2012. DOI: 10.1007/s00521-012-1016-0.

[4] Dyduch J., Paś J., Rosiński A.: Basics of maintaining electronic transport systems. Publishing House of Radom University of Technology, Radom 2011.

[5] Epstein B., Weissman I.: Mathematical models for systems reliability. CRC Press / Taylor \& Francis Group, 2008.

[6] Kałużny P.: Telewizyjne systemy dozorowe. WKiŁ, Warszawa, 2008.

[7] Laskowski D., Łubkowki P.: The end-to-end rate adaptation application for real-time video monitoring, Advances in Intelligent Systems and Computing, Springer International Publishing AG, Switzerland, Volume 224, 2013. p. 295-305.

[8] Laskowski D., Łubkowski P., Pawlak E., Stańczyk P. Anthropo-technical systems reliability. Safety and Reliability: Methodology and Applications Proceedings of the European Safety and Reliability Conference, ESREL 2014, p. 399-407.

[9] Mikulski J.: Using telematics in transport. 10th International Conference Transport Systems Telematics TST'10, Katowice Ustroń 2010, p. 72. 
[10] Nowakowski T.: Problems of reliability modelling of multiple-phased systems. Eksploatacja I Niezawodnosc-Maintenance And Reliability, Issue: 4, 2011, p. 79-84.

[11] Nowakowski T., Werbinska-Wojciechowska S.: Data gathering problem in decision support system for means of transport maintenance processes performance development. Safety and Reliability: Methodology and Applications - Proceedings of the European Safety and Reliability Conference, ESREL 2014, p. 899-907.

[12] Paś J., Duer S.: Determination of the impact indicators of electromagnetic interferences on computer information systems. Neural Computing \& Applications 2012. DOI:10.1007/s00521-012-1165-1.

[13] PN-EN 50132-1:2012P - Systemy alarmowe. Systemy dozorowe CCTV stosowane w zabezpieczeniach. Część 1: Wymagania systemowe.

[14] PN-EN 50132-7:2013-04E - Systemy alarmowe. Systemy dozorowe CCTV stosowane w zabezpieczeniach. Część 7: Wytyczne stosowania.

[15] Rosinski A., Dąbrowski T.: Modelling reliability of uninterruptible power supply units. Eksploatacja I Niezawodnosc - Maintenance and Reliability, Vol.15, No. 4, 2013, p. 409-413.

[16] Siergiejczyk M., Paś J., Rosiński A.: Application of closed circuit television for highway telematics. The monograph „Telematics in the transport environment", editors: Jerzy Mikulski, given as the monographic publishing series - „Communications in Computer and Information Science”, Vol. 329. The publisher: Springer-Verlag, Berlin Heidelberg 2012, p. 159-165.

[17] Siergiejczyk M., Paś J., Rosiński A.: Evaluation of safety of highway CCTV system's maintenance process. Monografia „Telematics - support for transport" pod redakcją Jerzego Mikulskiego, wydana jako monograficzna seria wydawnicza - „Communications in Computer and Information Science”, Vol. 471. Wydawca: Springer-Verlag, Berlin Heidelberg 2014, p. 69-79.

[18] Siergiejczyk M., Rosinski A.: Reliability analysis of electronic protection systems using optical links. The monograph „Dependable Computer Systems", editors: Wojciech Zamojski, Janusz Kacprzyk, Jacek Mazurkiewicz, Jarosław Sugier and Tomasz Walkowiak, given as the monographic publishing series - „Advances in intelligent and soft computing", Vol. 97. The publisher: Springer-Verlag, Berlin Heidelberg (2011). p. 193-203.

[19] Siergiejczyk M., Rosinski A.: Reliability analysis of power supply systems for devices used in transport telematic systems. The monograph „Modern Transport Telematics", editors: Jerzy Mikulski, given as the monographic publishing series - „Communications in Computer and Information Science”, Vol. 239. The publisher: Springer-Verlag, Berlin Heidelberg (2011), p. 314 319.

[20] Stapelberg R. F.: Handbook of Reliability, Availability, Maintainability and Safety in Engineering Design. Springer-Verlag, London 2009. 
Reliability and maintenance analysis of CCTV systems used in rail transport Analiza niezawodnościowo-eksploatacyjna systemów monitoringu wizyjnego...

[21] Sumiła M., Siergiejczyk M.: Method of dynamic identification of hazardous driver behavior by traffic parameters detection. Safety and Reliability Methodology and Applications - Nowakowski et al. (Eds). CRC Press Taylor \& Francis Group. London 2015. p. 109 - 114.

[22] Wydro K.: Telematics - significance and definition of the term. Telecommunication and IT. Publishing House of National Institute of Telecommunications, Warsaw 2005.

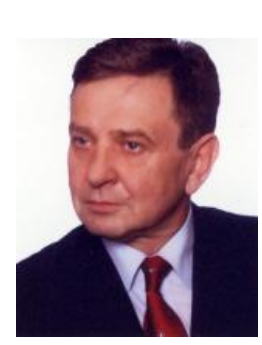

Mirostaw Siergiejczyk, Assistant Professor, PhD., Eng. - the coauthor of the paper's research interests include, among others, problems of architecture and services of telecommunication systems and networks with particular emphasis on their use in transport, reliability and maintenance of ICT systems and networks, modelling, design and organization of ICT networks and systems in transport.

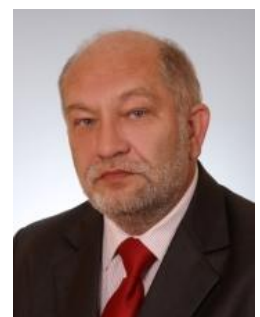

Jacek Paś, PhD Eng. - he defended his doctoral thesis at the Kazimierz Pulaski University of Technology and Humanities in Radom, at the Faculty of Transport and Electrical Engineering, in Poland, in 2010. Currently, he is an assistant professor at the Department of Electronics of the Military University of Technology. His research interests include: electromagnetic compatibility of low frequencies operation, maintenance of electronic safety systems, reliability and maintenance of complex systems.

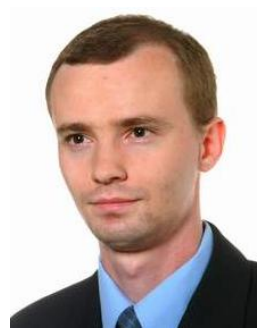

Adam Rosiński, PhD Eng - the co-author of the paper's research interests include reliability and maintenance analysis of transport telematics systems and intelligent transport systems. Several dozens of academic publications are his scientific achievements. 